\title{
Green Accounting Based Maslahah to Realizing University Social Responsibility in Indonesia
}

\author{
Muhammad Wahyuddin Abdullah ${ }^{1 *}$ Memen Suwandi ${ }^{1}$ \\ Andi Yustika Manrimawagau Bayan ${ }^{1}$ Hadriana Hanafie ${ }^{2}$
}

${ }^{1}$ Department of Accounting, Alauddin State Islamic University of Makassar, Makassar, Indonesia

${ }^{2}$ Department of Accounting, Wira Bhakti Economic High School of Makassar, Indonesia

${ }^{*}$ Corresponding author. Email: wahyuddin.abdullah@uin-alauddin.ac.id

\begin{abstract}
Business organization this time is expected look the environmental side based on Islamic values that exist in each of their activities. The purpose of research's to know application of Green Accounting concept when paired with Maslahah to realize university social responsibility, one of universities in Indonesia. This a qualitative research with phenomenological approach. The results of this research show that the social responsibility in Alauddin State Islamic University of Makassar Indonesia has been good with policy given by university leadership. This concept has involvement of environment as maintenance against five concepts of maslahah namely religion, soul, mind, family and property.
\end{abstract}

\section{Keywords: Green accounting, maslahah, university social responsibility}

\section{INTRODUCTION}

The environmental issue in this time is no longer a new issue which is just discussed. Some countries have paid considerable attention to the issue of environmental damage, such as air pollution, soil pollution, water pollution, and there are social gaps in the environment itself. [1] In his research stated that as the human population grows, thus increasing every activity that is done by man in order to fulfil his needs and survival and of course from the various activities that are carried out will have a considerable impact from the surrounding environment, namely environmental pollution. The company has the responsibility to maintain the surrounding natural environment in terms of natural resources management [2].

The concept of green accounting has begun to develop in Europe since the 1970, coupled with the development of research related to the issue of green accounting in the year 1980 [3]. Green Accounting is one of the efforts to preserve the environment that is seen from the accounting side [4]. In addressing environmental damage, environmental accounting is used as a good solution because it is regarded as a form of accountability of the Organization for the management and impact of environmental damage resulting from the operation of the company or organization. In the research of Santoso [5], that an organization can be categorized in maintaining the environment if it has an environmental awareness, hereinafter followed by the involvement of the organization to environmental issues. This should be followed by environmental reporting, primarily on organizational performance overcoming the impact of organizational activity on the environment [6]. Green accounting requires an environment of accounting system that can be used as a responsibility controller of the environment, because the waste shall that doing certainly require measurement, assessment, disclosure and reporting of the cost of process waste is green accounting [7].

Indonesia's current practices are still not effective. In Indonesia, accounting standards used as a reference have not required universities to disclose social information relating to activities conducted, especially in the responsibility of the college to the environmental impact of the activities undertaken [4]. The inability to make the college should assess its benefits and losses before deciding whether to implement USR or not. Based on the assumption of the inaction this research aims to analyse the extent to which green accounting has been applied to university in South Sulawesi Indonesia. The college has essentially sought to implement an environmentally friendly college condition. With this research all of authors hoped that can contribute to the fields of economic, accounting, environmental knowledge and the scope of applied science and company in order to get more attention to the environment. In this research the subject of research is Alauddin State Islamic University of Makassar.

The Islamic college in Makassar Indonesia has teamed up with SILE-LLD Canada and after composing the academic manuscript of the environmental Management policy of Alauddin State Islamic University of Makassar 2016 with them team. Written SWOT analysis on the academic manuscript, there are 7 (seven) things that mention is a weakness about the environment of Alauddin State Islamic University of Makassar namely (1) Planning aspects are still weak; (2) Absence of regulation on the environment; 
(3) Low budgeting aspect; (4) Awareness of the environment that is still lacking in the academic society; (5) does not have a special field that handles environment; (6) weak social control; and (7) have not been reporting monitoring and evaluation of the document of Analysis about environment impact in Alauddin State Islamic University Makassar. Furthermore, this research aims to find out how the Green Accounting is based Maslahah to realization University Social Responsibility of Alauddin State Islamic University of Makassar.

\section{LITERATURE REVIEW}

\subsection{Maslahah Concept}

Maslahah has various definitions of various scholars, including Imam Al-Ghazali make definition it as an image of benefiting or avoiding harm. However, it is not intended to achieve a benefit and to avoid the goal of human welfare in achieving its intention, maintaining or safeguarding the objectives of Syara. The other scholars of Imam Al-Khwarizmi mentioned that Maslahah is to preserve the purpose of Syara' by avoiding the poverty of human beings. According to Ramdhan al-Buthi, said that Maslahah is the benefit intended by the wisest God for the sake of his servants, whether it is to keep their religion, soul, mind, family, and property in the order that in the category of his observance. So, in general, the Maslahah can be interpreted as everything that has the benefits we can do or do and move away from things that contain something lacking or unfortunate. The concept of maslahah or knowledge of the principle of Maslahah is the principle with an indication that provides a reflection of Islam that emphasizes how important a consideration such as general consideration of the individual's interests [8].

\subsection{Legitimacy Theory}

The theory of legitimacy originally came from a concept of legitimacy of the organization expressed in 1975 by Dowling and Pefeffer stating that legitimacy is a state or status that exists when a congruent entity value system with a broader community-value system on which the entity is located. Lindblom 1994 say that the change in values and social norms will make a shift in legitimacy in society and a company is required to understand and adapt the changes that exist so that the company's sustainability will be assured. The fundamental thing of the theory of legitimacy according to [9] between companies and communities occurs social contracts in which the company operating and uses economic resources. The company has social contracts with the surrounding environment and by means of disclosure it is hoped that the company gained legitimacy that would have an impact on the company's survival [10]. The theory of legitimacy recognizes explicitly that the business is limited by social contracts that make the company agree to showed every social activity done.

\subsection{Green Accounting}

Green Accounting is the merger of information between the cost and benefits of the environment into various accounting practices and the merger of environmental costs into business decisions [11]. Companies that are already aware of their environment will get legitimacy from the society. Green Accounting can also provide information on how far the company's positive and negative contributions to the environment. For a company that implements Green accounting, they has business sustainability and one of the strategic factors to develop the company in the future [12]. The purpose of green accounting is to provide information about the operational performance of the company based on environmental protection. The motivation to report environmental problems that occur in a company is more dominated by its volunteering factor [13]. Motivation can be considered as a passion for work caused by other reasons rather than money or status, as well as a great wish to achieve goals with energy and perseverance [14].

In addition to volunteering, it can also be said that society is an important factor for the preservation of the company's good relationships with its environment, by preserving the environment around the company so that people do not feel disturbed with various environmental problems that will occur when not handled by the awareness of the company's internal parties.

\subsection{University Social Responsibility}

The college can not escape from Tridharma, namely education and teaching, research and society service [15]. In connection with Tridharma College is a devotion to the society, with the devotion to society, it is hoped to the internal community of universities to be more aware of the things that can have a positive impact on the environment and surrounding societies. The society is also expected to be cooperation if the College has activities involving the environment and its people to maintaining a harmonious relationship each the parties. The activity of university social responsibility society dedication are more devoted to the stakeholders in college.

\subsection{Maslahah to Support Green Accounting}

Maslahah is interpreted as taking the benefit of a thing and away from the inauspicious or unfortunate things that can even harm. As in the book of Lisanul Arab that the maslahah contains the meaning of a benefit, whether it is from Origin or from a process, example like produce pleasure and benefits, or care and prevention and also such as avoiding the danger [16]. If the stakeholders in college have awareness of the safeness of the people, especially in the society and surrounding environment, it will bring a benefit or a thing that is positive value between the two parties. Although the stakeholders have an awareness of the surrounding matter for the benefit of the people, but he 
does not do something or does not have an attempt to take corrective action, it is included in the unfortunate case.

\subsection{Green Accounting to Realizing University Social Responsibility}

The preparation of financial statements so far is focused on the interests of investors and creditors, but on the other hand ignore external factors from the operational activities they are doing such as soil pollution, water, air and others [17]. With the presence of green accounting or environmental accounting, it is expected that the organization discipline in the processing of waste from the operational activities of the company can make a variety of problems in the surrounding environment.

\section{METHODS}

The type of research that will be used in this research is qualitative research. Trying to construct reality and understanding the mean is the style of this study. The type of research used in this research is qualitative research with a phenomenological approach. Research with a phenomenological approach will know how human consciousness will be surrounding environment through a concept of maslahah so that it can apply green accounting based on shariah principles so as benefits for the whole people. The data source used by researchers is primary data and Secunder data. Primary data is data whose source is directly obtained from the original source and does not use intermediate media [18]. Primary Data is used to answer questions from the researcher. Secondary data that is a reference or supporter of the research conducted are journals from previous researchers. The term used in this study for research subjects was informant. This research looks at the representation of the informant represented by the quality of information provided by the informant, not seen from how many informants involved in the research.

\section{FINDINGS AND DISCUSSIONS}

\subsection{University Social Responsibility at Alauddin State Islamic University of Makassar}

Tridharma is one of the universities that is devoted to the community and has an institution that is the Institute of Research and Society Service. The task of the institution is to coordinate, monitor, implement and assess research activities and service to the society based on the Rector's policy. It is affirmed by one of the informants that:

"The university's role is very large in achieving the existing environmental arrangement circled by Alauddin State Islamic University of Makassar. Therefore, the responsibility is at the level of the rectorate. Well, this we have seen the various developments that are done by the Rector and his ranks, in this case against the environmental reforestation. In addition, the environmental damage I see is not significant. Well, this pack of leaders must be concerned to do the improvement to anticipation the negative impact "

Based on the results of the interview, it can be concluded that Alauddin State Islamic University of Makassar Indonesia responsibilities to the environment are good enough to give attention to the environment. This was seen in achieving the existing environmental arrangement circled by Alauddin State Islamic University of Makassar Indonesia and also from various new policies issued by the university leadership as an appeal in regards to the environment. Alauddin State Islamic University of Makassar Indonesia not only has the university's social responsibility to produce many bachelors, but has developed in such a way the social responsibility of the form of its instance. The university in this time viewed as a versatile institution, powerful and trustworthy in terms of answering or solving various types of problems that exist in the lives of surrounding society. An institution must be able to carry out its operational activities based on the expectations of the surrounding society so that there will be no conflict that could impede the implementation of the activity of the instance based on the theory of legitimacy that emphasizes on how important a institutional is capable of having the society.

In addition, Alauddin State Islamic University of Makassar Indonesia still needs various improvements in order to fulfil its responsibilities for the better, not only the with the word is enough to fulfil its social responsibility. Various improvements are also expected from the activity has not yet taken by university's leadership. Like the implementation and utilization of the space that is not the maximum because the university has not the consistency to implement what has been planned. Furthermore, related to the damage that occurred in the environment of Alauddin State Islamic University of Makassar Indonesia, but not yet seen as significant problem as the absence of water lines inside the campus that caused every rain, water was flooded on the road and made a scene that is less from the looking. If it is not followed up, then it will cause serious problems such as it could be flooding when the aqueduct is not noticed early and it will impact back to the university image that will be damaged. The informant is a student who expressed his opinion on the issue in the university that:

"If I see at Alauddin State Islamic University of Makassar Indonesia, there is no specific monitoring for the environment, because there is still a lot of garbage scattered, although only in particular area, so in my opinion there needs to be a change or concern from the students themselves to maintain the environment." (Informant, student)

"Sometimes we are also confused when we want to dispose of garbage, our distance to the dump is very far. So, this needs to have more improvements with the dump there in the campus that is especially in the roadside of the road. Around 10 meters there is dump, so it is easy to get rid of garbage. Because in the building is still minimal with the dump. " (Informant, student) 
Based on environmental problems, there are verses that discuss the environment is a commandment to safeguard the environment and prohibition to damaging the environment, as in qur'an Ar-Rum verse 41-42:

"There has been damage on land and in the sea because of the act of the people, that God might feel to them part of their deeds, that they may return (to the right way). Say: "Seek the journey on the Earth, and see how the end of those who were past. Most of them are allying to Allah" The verse explains that Allah created people on the Earth as a caliph who has the duty and obligation to manage, preserve and utilize the nature that God has created for the welfare and the sake of all beings of God. The absence of human concern for natural resources has an impact on the damage environmental of the poor. Fiqh, which is one of the most dominant Islamic sciences in the life of Muslims, explains in substance, the Fiqh of the Environment (Fiqh Al-Biah) seeks to make the believers aware that the environment cannot be separated from the responsibilities of human beings who have faith and the mandate of his own [19].

\subsection{Green Accounting as Benefit at Alauddin State Islamic University of Makassar}

\subsubsection{Environmental awareness based on religion, mind, family and property}

Attention to the new surroundings will be realized as soon as some environmental damage occurs. It is due to human indifference of the circumstances around very less. Building awareness of the environment for individuals who are not very understanding and committed to the importance of the environment becomes a solid foundation to be a good observer of the environment. Awareness can be started from motivation. Motivation is a feeling or personal state of diverse origin. It has a subjective character and is directly related to a person's degree of motivation and his / her desire to be motivated [20]. Here are some responses to the university's concern about the surrounding environment that:

"Yes university was care, because there are already units that are under the auspices of society devotion, such as civilization units and all already have a budget in each unit (informant)."

"That campus cares enough to be seen because look from the budget for the improving social responsibility (informant)."

From the interview above, it can be concluded that the university has enough care about its environment, can be seen from various units formed to be a proof that the environment has an impact for the university, so it is appropriate if the environment is very important to be noticed. In addition, as another form of attention of the university to its environment by holding a budget that can be said in a considerable amount and the Rector Pancacita in non-academic which one of them has a beautiful campus, meaning Alauddin State Islamic University of
Makassar Indonesia can be said as a campus of civilization if it has a beautiful environment.

The Program that has been presented by the university will be much more effectively achieved when all the campus community is campus students, lecturers and employees are involved in safe the environment, and the beginning of the form of care that is awareness of the importance of the environment around us. A trivial little thing that can be made for example is that one person who is able to dispose of garbage in his place will make the surroundings can change the perspective of other individuals into a positive perspective on the environment that is conscious of the self-made and the impact on oneself and the environment. The Islamic religion teaches how humans contribute to the civilization of harmony with nature. In the midst of human life nowadays it is known only that jurisprudence only deals with human relations with human beings. Because of this, the fiqh of social related is neglected, such as environmental problems that are still neglected. The verses related to preventing environmental damage include qur'an An-Nisa verse 114 [21]:

"There is no good interest in most of their whisles, except the whisking of those who ask (people) to give charity, or do Ma'ruf, or to make peace between humans. And Whoso is doing this because of the search of Allah's rhida, then we give him a big reward."

The prevention of environmental damage is not carried out on an outward basis, but also required the awareness of each individual (human) who has faith and is not separated from his faith [22]. In the tafseer of the Republic of Indonesia about Q.S An-Nisa, verse 114 mentions that Allah is unwilling to carry out three kinds of Commandments, namely charity, to do good and to seek peace among people and to the subjection of the heart and obedience to God and seek the willingness of Allah. So it is for them that reward multiplied by God. The willingness of Allah can only be obtained by doing good and can be beneficial is also accompanied by a sincere heart of what He Commands.

\subsubsection{Environmental involvement based on religion, mind, family and property}

Subjectively perceived group activity and the ability to concentrate for a long time only on the training task [23]. As for the size of the university in environmental involvement, namely the center of civilization of Islamic civilization and the availability of budgets for the maintenance of the environment.

\section{The existence of center for Islamic Civilization}

Having an institution that oversees the management and preservation of the environment is very important. It is said to be a campus of civilization when it has beautiful environment such as Pancacita Rector in non-academic. The presence of an institution is none other than the awareness of the environment itself. With the center of Islamic civilization is expected to support in the preservation of the environment. Besides being used as a 
container for environmental preservation, the center of Islamic Civilization is also responsible for the university environment as a form of university social responsibility, and can create a good image for the university.

\section{Availability of environmental budgets}

The university generally enters the cost of the environment in maintenance costs. An environmental budgeting in Alauddin State Islamic University of Makassar Indonesia is doing in annually. The budgeting that is held related to the environment in Alauddin State Islamic University of Makassar Indonesia is a form of social responsibility both from the environment within the university and also to the outside environment of the university. The Islamic image of the environment can be seen in one of the Qur'an verse: "Why they don't think about (the incident) themselves? Allah does not make the heavens and the earth and what is between them but with the correct (purpose) and time specified. And indeed most among they are truly unrighteous to be meetings with his God."

Based on the verses, it can be seen that the environment is recognized or not, the law of preservation of the environment is mandatory and unlawful to damage it. Likewise, when associated with five basic concepts (AlDharuriyah), namely religion, soul, mind, family and property, then the five concepts are associated with the preservation of the Environment [24]

\subsubsection{Environmental Reporting Based on Religion, Mind, Family and Property}

Environmental reports are the type of information needed and used by the society in order to know the values of the company in terms of governance, value, strategy, and also the commitment of the company in answering environmental and social issues. Accounting standards in Indonesia are still not obliging university parties to disclose social information relating to social activities, especially the university's responsibility for environmental impacts caused by various university activities. Disclosure is required because of the importance of the environment and the destructive impact of cor-porate activities on the environment [25]. Publishing of environmental accounting reports would work well as an agency tool to meet the environmental obligations by company for accountability to stakeholders and as a fair way of evaluating conservation activities [26].

The university has not only responsibility for social and economic, but has a responsibility to nature [27]. Human is present as the Caliph or guardian of God on Earth to manage his riches. Nature conservation is a form of environmental responsibility that is done by human beings because it uses nature as a means of various activities. It should be a duty that human can be the caliph on the Earth as the verse contained in the Qur'an:

"He is the one who makes you a caliph on the earth. Whoso, the unbelievers (as a consequence) of his own. And the disbelievers of those who disbelieve will not only add wrath to the sides of his God and the unbelievers that the disbelievers will not only increase their loss fine."

Table 1 show that Human as the caliph on the earth is present not only to worship to God, as it is mandatory to do all religious rituals (prayer, fasting, zakat, charity, etc.) but have the obligation to preserve the universe and its contents with hope of benefit for himself and also others. It remains to refer to the five basic concepts of alDharuriyah, namely religion, soul, mind, family and property.

\subsection{Green Accounting Reccomendation Based Maslahah to Realizing University Social Responsibility}

God gives the intelligent excess, a sublime feeling, a keen mind and also an extraordinary ability in human to perform his duty as a caliph on the earth. The university is expected by the concept of green accounting, so the organization is able to assess that maintaining, protecting and maintaining the environment is a must to be $\mathrm{d}$ one. The Qur'an has selected human beings in his duties as Caliph on Earth, relating to environmental conservation. So that, the generation requires that human perform duties in accordance with God's instruction in qur'an al-Baqarah verse 30:

"Remember that when your God said to the Angels,"Actually I will make a caliph on the earth. "They said: "Why do you want to make (caliph) on the Earth the human who will make damage to him and shed blood, but we always celebrate to praise thee and purify thee? "The God said: "Actually I know what you do not know."

The verse explains that the appointed human as Caliph on the earth is not a ruling without reason or just a coincidence, but because God knows that his servant (human) can carry it out. The presence of the verse above, it is indirectly used as a caliph on the earth to develop its knowledge, such as the importance of green accounting seen based on Maslahah to be more aware or foster a sense of human concern about the importance of maintaining, protecting and maintaining the environment where the organization is located. It remains to refer to the five basic concepts of al-Dharuriyah, namely religion, soul, mind, family and property. 
Table 1 Concept recommendation of green accounting based maslahah

\begin{tabular}{|c|c|c|}
\hline No & $\begin{array}{c}\text { Maslahah } \\
\text { Concept }\end{array}$ & Green Accounting \\
\hline 1. & Religion & $\begin{array}{l}\text { It takes responsibility of what has been done in regards to environmental } \\
\text { preservation. Responsibility of human consciousness is divided into two, } \\
\text { that is, the vertically accountability (to God) and horizontally } \\
\text { accountability (to the human). }\end{array}$ \\
\hline 2. & Soul & $\begin{array}{l}\text { If people do not maintain their environment, such as land, water, air, it } \\
\text { can cause an impact on the destruction of human existence. Humans are } \\
\text { obliged to limit themselves, that being able to judge which is good and } \\
\text { bad for themselves and others. }\end{array}$ \\
\hline 3. & Mind & $\begin{array}{l}\text { Good mind lies in a healthy body, so the related part is a clean } \\
\text { environment, because the clean environment is one of the causes or } \\
\text { supporters in creating a healthy and good body condition. }\end{array}$ \\
\hline 4. & Family & $\begin{array}{l}\text { The continuity of human life also depends on the surrounding area and } \\
\text { the resources they have. Looking at the meaning of Surah An-Nisa verse } \\
9 \text {, and if their lives (previous generations) do not have faith, have no good } \\
\text { environment, then it can ruin the lives of their next generation. }\end{array}$ \\
\hline 5. & Property & $\begin{array}{l}\text { Human beings are involved in the preservation of the environment, } \\
\text { because natural resources are a must-protect and safe for human needs } \\
\text { and survival. Religions teach people to avoid the attitude of consumerism } \\
\text { or an inefficient lifestyle that can lead to the imprecision of economic } \\
\text { resource allocation. }\end{array}$ \\
\hline
\end{tabular}

Table 1 show that he five fundamental concepts (AlDharuriyah) have involvement with the preservation of the environment. Thus, the care of the five concepts can lead to the good of human life, likewise by making it a new concept, expected to fulfill the university's social responsibility will be the value of adding in terms of the quality of social and economic life of the society.

The obligation to maintain the environment based on religion, fiqh rules explaining "Maa la Yatimmu alwajib Illa bihi fahuwa al-wajib" (something that must not be perfect except with him, then it becomes duty) means that maintaining the environment is duty in the case of preserve religion. human as Caliph on Earth held responsibility for what he had done in relation to the preservation of the environment. Accountability is seen from human consciousness divided into two, which are vertical accountability and horizontal accountability [28]. The meaning of vertical accountability is accountability to God and the horizontal accountability is accountability to human beings in the form of financial statements. Qur'an Al-Isra verse 36:

"And do not follow what you have no knowledge. Indeed, hearing, vision, and heart, they will be asked for the responsibility."

The obligation to maintain the environment to the soul has direct relation with maintaining the environment. As for the form of human destruction in the environment such as landslides, flooding and so on as a form of destruction to the existence of human soul. Then human is obliged to be able to restrict himself that being able to judge good and bad for oneself and others or is obliged to nurture the human psyche.

The obligation to maintain the environment against mind is also ordered by Islamic religion. Good sense mind in the healthy part of the body. This means that the health of the mind is associated with a person's body condition. Then an obligation to have a clean environment. Because a clean environment is one of the causes or supporters in creating a healthy and good body condition. Thus, the obligation to maintain a similar environment with the obligation to maintain against mind.

The obligation to maintain the environment of family is one of the Shari'ah that is compulsory in humans. Familiy who do not have faith, do not have good environment and so on, if they leave their children in rich state, then it is better than they died in poor condition that begging in others (Hadits by Bukhari and Muslim). The continuity of human life also depends on the surrounding area and the resources they have. Furthermore, with the reporting or form of accountability for the environment either vertically or horizontally, it can be instrumental in adding knowledge for families especially children who have a living pattern tend to follow the lifestyle of parents.

The maintenance obligation to the property is to have a huge responsibility. One of them in order to avoid consumerism behavior (can be interpreted as an inefficient lifestyle) that can lead to the imprecision of economic resource allocation. Thus, it can protect the property, so it is necessary to maintain the environment because the natural resources are a property that must be protected and maintained for human survival needs.

\section{CONCLUSIONS}

Based on the results of the research and discussion that has been described, in the research thesis can be withdrawn, namely Alauddin State Islamic University Makassar Indonesia, famous as a University of civilization with its 
vision as the Center of enlightenment and transformation of science based Islamic civilization. Alauddin State Islamic University Makassar Indonesia has been good enough in carrying out its university responsibilities to the surrounding environment. Judging from the arrangement of the environment in Alauddin State Islamic University Makassar Indonesia and from various policies and appeals that have been issued by the university leadership. Alauddin State Islamic University Makassar Indonesia a concern for the environment and engaged in a problem of the environment, so it can be said that the university has participated in the maintenance of its environment. Green Accounting as a concept of environmental accounting system that can be used as a controller of responsibility to the environment and some elements of green Accounting that is discussed namely environmental awareness, environmental involvement and environmental reporting. As a campus of civilization, Alauddin State Islamic University Makassar Indonesia is famous for its knowledge integration, like the research is pairing green accounting based on Maslahah with five basic concepts namely religion, soul, mind, family and property.

Green Accounting based on Maslahah has involvement with the environment, as well as the maintain of the five concepts of al-Dharuriyah namely religion, soul, mind, family and property can give good to human life. It can also provide responsibility to the society as part of the University Social Responsibility. Alauddin State Islamic University Makassar Indonesia has a difference with other universities, because Alauddin State Islamic University Makassar Indonesia apply religious values in every step towards Islamic scholarly nobility and concern for this time problems of society's life.

Authors will provide suggestions to understand how importance of environmental maintenance that you will have an impact. With the attention of concern about the environmental that arises on themselves even in an organization, it can make an extraordinary movement and positive impact, such as good image and responses from the society around university. For future research is also expected to be able research the environmental from various perspectives that can also bring goodness like maslahah

\section{ACKNOWLEDGMENT}

The author would like to acknowledge that the financial support by provided by Alauddin State Islamic University of Makassar from research grant and corresponding author.

\section{REFERENCES}

[1] I. A. R. Prihatiningtias 2019 Akuntansi Hijau dan Industri Perhotelan: Sebuah Keniscayaan. Jurnal Economica, 15(2), pp. 189-208.
[2] J.P. Queille, J. S. Lubis, H, A, Diani. 2018 Analisis Penerapan Akuntansi Lingkungan (Green Accounting) Dalam Pengelolaan Limbah Perusahaan. Prosiding Konferensi Nasional ke-8 Asosiasi Program Pascasarjana Perguruan Tinggi Mummadiyyah Aisyiah, pp. 1-17.

[3] C. Baier, J-P. Katoen, Principles of Model Checking, MIT Press, 2008. Astuti, Neni., (2012). "Mengenal Green Accounting". PERMANA, 4(1), pp. 69-75.

[4] F. Astuti, 2017 Analisis Green Accounting Berbasis University Social Responsibility (USR) (Studi Komparasi pada Perguruan Tinggi di Wilayah Yogyakarta dan Surakarta. Jurnal Nominal, 1(1), pp. 116.

[5] S. Santoso, 2016 Konsep Corporate Social Responsibility dalam Perspektif Konvensional dan Fiqh Sosial AHKAM, 4(1), pp. 81-103.

[6] W. Astiti, 2014 Implementasi Green Accounting Berbasis University Social Responsibility (USR) di Universistas Negeri Yogyakarta. Jurnal Nominal, 3(2), pp. 134-149.

[7] M. W. Abdullah, dan A. Yuliana 2018 Corporate Environmental Responsibility: An Effort To Develop A Green Model. Jurnal Akuntansi, 12(3): 305-320. https://dx.doi.org/10.24912/ja.v22i3.390

[8] F. Amelia, 2018 Environmental Accounting dalam Konsep Sosial Maslaha: Sebuah Pendekatan Kritis (Studi Pada PT. PP London Sumatra Indonesia Tbk. Palangsian Estate). Skripsi. Makassar: Fakultas Ekonomi dan Bisnis Islam UIN Alauddin.

[9] G. O'donovan, 1999 Managing Legitimacy Throught Increase Corporate Environmental Reporting. Interdisciplinary Environmental Review, 1(1), pp. 6399.

[10] L. A. M. Puspita, 2015 Corporate Social Responsibility: Implikasi Stakeholder dan Legitimacy GAP dalam Peningkatan Kinerja Perusahaan. Jurnal Akuntansi Multiparadigma, 6(1), pp. 1-18.

[11] Amiruddin 2012 Etika Lingkungan dalam Pengelolaan Lingkungan Hidup. Jurnal Nominal, 3(1), pp. 137-147.

[12] D. Pratiwi, Y. Pravasanti, 2018 Analisis Penerapan Green Accounting pada Industri Batik Laweyan. Jurnal Nominal, 3(2), pp. 536-550. 
[13] A. Ball, 2005 Environmental; Accounting and Change in UK local government. Journal Accounting, Auditing and Accountability, 18(46), pp. 366-473.

[14] N. Israfilov, O. Borisova, O. Kartashova, N. Davydova, G. Biserova, and A. Gryaznukhim, 2020. Motivation and Employee Effectiveness in Online Learning Environments: Leadership Strategis of New Generation and Emotional Intellect. International Journal of Emerging Technologies in Learning (iJET), 15 (9): 258-279. https://doi.org/10.3991/ijet.v15i09. 139214

[15] S., Silalahi, A 2014 Implementasi Tanggung Jawab Sosial Perguruan Tinggi dan Dampaknya Terhadap Citra Kampus di Universitas Nusantara PGRI Kediri. Nusantara of Research, 1(2), pp. 192-205.

[16] A. Qarib, I. Harahap 2016 Penerapan Maslahah Mursalah Dalam Ekonomi Islam. Analityca Islamica, 5(1), pp. 55-80.

[17] I. Adnyana, I. Atmadja, N. Herawati, 2017 Analisis Penerapan Akuntansi Lingkungan pada Badan Usaha Milik Desa untuk Mewujudkan Green Accounting (Studi pada BUMDes Desa Tajun, Kecamatan Kubutambahan, Kabupaten Buleleng, Provinsi Bali. E-jurnal Universitas Pendidikan Ganesha, 8(2), pp. 1-11.

[18] U. H. Rahmawati, 2014 Pengaruh Beban Kerja dan Pengalaman Audior dalam Mendeteksi Kecurangan". Jurnal Akuntansi dan Investasi, 15(1), pp. 68-76.

[19] W. D. Farida, 2017 Akuntansi Lingkungan: Kajian Penerapan dalam Perspektif Islam (Studi Kasus pada Perusahaan yang Tercatat di Jakarta Islamic Index (JII)). Seminar Nasional dan The 3rd Call for Syariah Paper, pp. 1-17.

[20] O. Navarro, J. M. Anguita, and A. L. Gonzalez, 2020. Motivation of University Student Towards the Use og Information and Communication Technologies and Their Relation to Learning Styles. International Journal of Emerging Technologies in Learning (iJET), 15 (15): 202-217. https://doi.org/10.3991/ijet.v15i15. 14347

\section{[21] Al-Qur'an}

[22] M. Ilyas, 2008 Lingkungan Hidup dalam Pandangan Islam". Sosial Humaniora, 1(2), pp. 155166.

[23] Z. Q. Liu, 2020 Co-Learning as a new Model of Learning in a Digital Environment: Learning Effectiveness and Collaboration. International Journal of Emerging Technologies in Learning (iJET), 15 (15): 34-48. https://doi.org/10.3991/ijet.v15i13.14667

[24] Abrar 2012 Islam dan Lingkungan”. Jurnal Ilmu Sosial Mamangan, 1(1), pp. 16-24.

[25] L. Nofianti, R. Anitaa, R. Anugerah, M. R. Abdillah, and N. B. Zakaria, 2018. Environmental Information Disclosure and Firm Valuation: Corporate Governance as Moderating Variable. International Journal of Engineering \& Teachnologi. 7 (3): 114-117. www.sciencepubco.com/index.php/IJET

[26] M. W. Abdullah, R. Mursani, A. Syariati, and H. Hanafie 2020. Carbon Emission Disclosure in Indonesia Firms: The Test of Media-exposure Moderating Effects. Internation Journal of Energy Economics and policy. 10(6),732-741. https://doi.org/10.32479/ijeep.10142

[27] N. Faridah, N. Saadah (2019). "Etika Pertanggungjawaban Lingkungan dalam Bingkai AlQur'an". EQUILIBRIUM: Jurnal Ekonomi Syariah, 7(2), pp. 343-366.

[28] M. W Abdullah, F. F. Yusuf, A. Y. M Bayan, 2020 Sustainability Governance; Reciprocation Accountability based Emotional Quotient". Technium Social Science Journal. 7(1), pp. 183-200. https://doi.org/10.47577/tssj.v7i1.452 